\title{
Iron-doped zinc oxide nanoparticles-triggered elicitation of important phenolic compounds in cell cultures of Fagonia indica
}

\author{
Atta Ullah Khan ${ }^{1} \cdot$ Tariq Khan $^{1}$ (1) - Mubarak Ali Khan ${ }^{2} \cdot$ Akhtar Nadhman $^{3} \cdot$ Muhammad Aasim $^{1} \cdot$ Nadir Zaman Khan ${ }^{1}$. \\ Waqar $\mathrm{Ali}^{1} \cdot$ Nausheen Nazir ${ }^{4} \cdot$ Muhammad Zahoor $^{4}$
}

Received: 9 March 2021 / Accepted: 9 June 2021 / Published online: 16 June 2021

(c) The Author(s), under exclusive licence to Springer Nature B.V. 2021

\begin{abstract}
The callus cultures of Fagonia indica could prove as factories for the production of important phytochemicals when triggered through different types of stress. In this study, we initiated callus cultures from healthy stem explants in the presence of iron-doped zinc oxide nanoparticles (Fe-ZnO-NPs). We performed experiments with the callus cultures of $F$. indica to determine the impact of Fe-ZnO-NPs in concentrations $(15.62-250 \mu \mathrm{g} / \mathrm{mL})$ on biomass accumulation, production of important phenolic and flavonoids, and antioxidative potential. Our results showed that maximum callus biomass [Fresh weight $(\mathrm{FW})=13.6 \mathrm{~g}$ and Dry weight $(\mathrm{DW})=0.58 \pm 0.01]$ was produced on day 40 when the media was supplemented with $250 \mu \mathrm{g} /$ $\mathrm{mL}$ Fe-ZnO-NPs. Similarly, maximum total phenolic content (268.36 $\mu \mathrm{g}$ GAE/g of DW) was observed in 40 days old callus added with $125 \mu \mathrm{g} / \mathrm{mL}$ Fe-ZnO-NPs. Maximum total flavonoid content (78.56 $\mu \mathrm{g}$ QE/g of DW) was recorded in 20 days old callus grown in $62.5 \mu \mathrm{g} / \mathrm{mL}$ Fe-ZnO-NPs containing media. Maximum total antioxidant capacity $(390.74 \mu \mathrm{g} \mathrm{AAE} / \mathrm{g}$ of DW) was recorded in 40 days old callus with $125 \mu \mathrm{g} / \mathrm{mL}$ Fe-ZnO-NPs treated cultures, respectively. Similarly, the highest free radical scavenging activity $(93.02 \%)$ was observed in callus derived from media having $15.62 \mu \mathrm{g} / \mathrm{mL} \mathrm{Fe}-\mathrm{ZnO}-\mathrm{NPs}$. The antioxidant potential was observed to have positive correlation with TPC $(r=0.44)$. HPLC analysis showed that Fe-ZnO-NPs produced compounds (e.g., Epigallocatechin gallate) that were either absent or in lesser quantities in the control group. These results showed that Fe-ZnO-NPs elicitors could increase the biomass and activate secondary metabolism in $F$. indica cells.
\end{abstract}

\section{Key Message}

Nanomaterial supplementation engineers the cells in an effective way to trigger biomass andsecondary metabolism for the production of important phenolic compounds in plant cells.

Keywords Callus culture $\cdot$ Fagonia indica $\cdot$ Elicitation $\cdot$ Iron-doped zinc oxide nanoparticles · Total phenolic content

Communicated by Konstantin V. Kiselev.

Tariq Khan

tariqkhan@uom.edu.pk

Akhtar Nadhman

shamsnazman@gmail.com

1 Department of Biotechnology, University of Malakand, Chakdara 18800, Dir Lower, Pakistan

2 Department of Biotechnology, Faculty of Chemical and Life Sciences, Abdul Wali Khan University Mardan (AWKUM), Mardan 23390, Pakistan

3 Institute of Integrative Biosciences, CECOS University, Peshawar, Pakistan

4 Department of Biochemistry, University of Malakand, Chakdara 18800, Dir Lower, Pakistan

\section{Introduction}

In vitro cultures of plants provide a model platform for studying their potential as factories for important medicinal compounds. In vitro cultures, including plant cell and callus cultures, can serve as factories of phytochemicals/secondary metabolites that can be produced in uniform quality to fight against many threatening diseases, including infectious diseases such as the currently pandemic COVID-19 (Khan et al. 2020b). The in vitro culture-based production of phytochemicals has an additional benefit of consistency in yield and quality (Khan et al. 2016). Different medicinal plant species are considered for developing cell cultures according to their pharmaceutical uses. These plants have analgesic, astringent, antioxidant, antitumor, prophylactic, 
and febrifuge activities. $F$. indica is an important species of the genus Fagonia. Numerous reports are available on its anticancer activity, fever, toothache, asthma, kidney diseases, urinary discharge, and stomach problems (Eman et al. 2010). However, inconsistency in clinical trials and lack of sustainable harvest strategies from field-grown wild plants cause problems in consistently producing phytochemicals. The establishment of the plant in vitro cultures can circumvent many issues in biomass production (Yousaf et al. 2019). Elicitation has been a handy tool for improved secondary metabolites' production in different medicinal plants in vitro cultures. The role of nanoparticles as abiotic elicitors for producing secondary metabolites from the in vitro cultures is a new frontier in metabolic engineering approaches (Khan et al. 2020a). These nanoparticles execute oxidative stress in the plant cells grown via in vitro culture techniques, activating their metabolism and enhancing antioxidant activities (Javed et al. 2018). Nanoparticles have a smaller size $(0-100 \mathrm{~nm})$ and large surface-to-volume ratio, due to which they reveal remarkable unique features. Nanomaterials can help in speedy plant germination and increase resistance to various abiotic and biotic stresses. They can improve plants' growth with lesser ecological influences than traditional methods (Alharby et al. 2016). Among different nanoparticles, zinc oxide nanoparticles (ZnO-NPs) have received more importance (Srivastava et al. 2013). Zinc oxide ( $\mathrm{ZnO}$ ) plays an active role in various regulatory functions and is involved in plants' response to abiotic stresses. It has been identified that Zinc has a vital role in the protection of plant cells against oxidative stresses and the management of reactive oxygen species (ROS) (Alharby et al. 2016). Studies have shown that Iron-doped Zinc oxide nanoparticles (Fe$\mathrm{ZnO}-\mathrm{NPs}$ ) have a high surface area and maximum catalytic activity than pure $\mathrm{ZnO}$ and $\mathrm{Fe}_{2} \mathrm{O}_{3}$ systems (Hassan et al. 2012). Therefore, this study was designed to assess the physiological and biochemical effects of Fe-ZnO-NPs on callus cultures of $F$. indica. This study aimed to evaluate the impact of the addition of Fe-ZnO-NPs on the biomass accumulation and production of medicinal metabolites in callus cultures of $F$. indica.

\section{Materials and methods}

\section{Plant material and culture conditions}

The seeds of $F$. indica were sterilized by treating them with $0.1 \%$ mercuric chloride solution. According to Khan et al., the seeds were dried on filter paper for 3-5 min before nicking the seeds speedy and efficient germination (Khan et al. 2016). Murashige and Skoog media (MS Media, M519 Phytotech lab USA) (Murashige and Skoog 1962) were used to grow plants such that $2.2 \mathrm{~g}$ of MS media was added with
$15 \mathrm{~g}$ of sucrose and $4 \mathrm{~g}$ of agar in $500 \mathrm{~mL}$ distilled water. The $\mathrm{pH}$ of the media was optimized to 5.2-5.8 before the optimization of $\mathrm{pH}$. After media preparation, $35 \mathrm{~mL}$ of the media was transferred to flasks covered with cotton and aluminum foil and were autoclaved and kept overnight for further use. Seeds were then transferred to media per flask, and the flasks were plugged with cotton and covered with aluminum foil properly to avoid contamination. The cultured flasks were transferred to a growth chamber (BioBase, BJPX-A1500C, Ltd. China) for germination. These growth conditions were maintained: humidity was $70 \%$, temperature $25 \pm 2{ }^{\circ} \mathrm{C}$, and illumination of 16-h light/8-h dark $\left(40 \mu \mathrm{mol} \mathrm{m}^{-2} \mathrm{~s}^{-1}\right.$; Philips TLD 35 fluorescent lamps).

\section{Callus culture initiation}

For initiation of callus cultures, the media was added with Thiadizuron (TDZ @ $1 \mathrm{mg} / \mathrm{mL}$ ) according to Khan et al. (Khan et al. 2016). The plant stem was cut into pieces $(5 \mathrm{~mm}$ in length), transferring two stem cuttings to each flask. The culture flasks were transferred to the growth chamber to initiate callus (BioBase, BJPX-A1500C, LTD CHINA). The conditions in the growth chamber were such that (humidity was $70 \%$, temperature $25 \pm 2{ }^{\circ} \mathrm{C}$, and a photoperiod (16-h light/8-h dark) to produce the callus biomass.

\section{Dispersion and supplementation of media with iron-doped zinc oxide nanoparticles}

Fe-ZnO-NPs were kindly provided by our collaborator at the Department of Biotechnology, Institute of Integrative Biosciences, CECOS University. The nanoparticles were characterized for size and morphology through transmission electron microscopy and X-Ray diffraction. The average diameter of these nanoparticles was $30 \mathrm{~nm}$ and were either square or hexagonal in shapes. A detailed data on the size, shape and other properties of these nanoparticles can be accessed via Zia et al. (2021). The dispersion of these nanoparticles was prepared in different concentrations of $\mathrm{Fe}-\mathrm{ZnO}-\mathrm{NPs}$ for the MS media $(250,125,62.5,31.25$, and $15.62 \mu \mathrm{g} / \mathrm{mL}$ ) were prepared in distilled water. The Fe- $\mathrm{ZnO}$ NPs were properly dispersed in stock solution by sonication (Power sonic 405, Korea) for an hour. After preparing the final concentration for $250 \mu \mathrm{g} / \mathrm{mL}$ Fe-ZnO-NPs, serial dilution was used to prepare the other concentrations. Afterward, approximately $0.4 \mathrm{~g}$ of callus was transferred to each flask containing $35 \mathrm{~mL}$ media with the different concentrations of Fe-ZnO-NPs (250, 125, 62.5, 31.25, and $15.62 \mu \mathrm{g} / \mathrm{mL})$. Callus without Fe-ZnO-NPs in the media was used as a control. The flasks were then transferred to allow the callus' growth in a growth chamber (BioBase, BJPX-A1500C, Ltd China). The callus culture samples were harvested on day 10 , day 20 , and day 40 from the initial callus transfer date. 
The fresh weight of callus was recorded after each harvest by an Analytical balance (AW 120, Electronic balance). The callus was then kept in a dry heat oven overnight at $35^{\circ} \mathrm{C}$ for recording the dry weight. The callus was then ground to fine powder, which was stored for further analysis.

\section{Analysis of the accumulation of secondary metabolites}

\section{Total phenolic content determination}

For the determination of TPC, $20 \mu \mathrm{L}$ of sample and $90 \mu \mathrm{L}$ of Folin-Ciocalteu reagent were added to a 96 wells microplate by a multi-channel micropipette. Then $90 \mu \mathrm{L}$ of sodium carbonate was added. After this, incubation of the microplate for $30 \mathrm{~min}$. Gallic acid concentrations $(25,20,15,10$, and $5 \mu \mathrm{g} / \mathrm{mL}$ ) were used as a positive control for the process. The absorbance of samples was recorded for TPC through a microplate reader (TSx800Absorbance Reader, BioTek Inc., USA). All the experiments were carried out in triplicate. All the experiments were carried out in triplicate.

\section{Total flavonoid content assay}

For the determination of TFC, $20 \mu \mathrm{L}$ of the sample, $10 \mu \mathrm{L}$ of Potassium acetate, $10 \mu \mathrm{L}$ of Aluminium Chloride, and $160 \mu \mathrm{L}$ of distilled water were added to a 96 well microplate. After this, incubation of the microplate for $30 \mathrm{~min}$. Quercetin final concentrations, $(40,20,10,5$, and $2.5 \mu \mathrm{g} / \mathrm{mL})$ were used positive control for the process. The absorbance was recorded for TFC through a microplate reader (TSx800Absorbance Reader, BioTek Inc., USA). All the experiments were carried out in triplicate. All the experiments were carried out in triplicate.

\section{Determination of antioxidative potential in response to Fe-ZnO-NPs}

The antioxidant activities were determined by the diphenyl picryl hydrazyl (DPPH) assay. The DPPH free radicle scavenging activity was performed such that $20 \mu \mathrm{L}$ of sample and $180 \mu \mathrm{L}$ of DPPH reagent were added to microplate wells and then incubated for an hour. Ascorbic acid $(40,20,10$, and $5 \mu \mathrm{g} / \mathrm{ml})$ used as a positive control for the assay. Similarly, the phosphomolybdenum method was used to determine the total antioxidants capacity of the sample. First, $180 \mu \mathrm{L}$ of total antioxidants capacity reagent (TAC) and $20 \mu \mathrm{L}$ of the sample extract were added to the 96 wells microplate. The mixture was then incubated in a water bath at $95{ }^{\circ} \mathrm{C}$ for $90 \mathrm{~min}$. After this, the sample was cooled down at room temperature. For drawing standard curves, $40,20,10$, and $5 \mu \mathrm{g} / \mathrm{mL}$ of ascorbic acid was a positive control for the assay. The absorbance of samples was recorded through a microplate reader (TSx800 Absorbance Reader, BioTek Inc., USA). All the experiments were carried out in triplicate.

\section{HPLC-UV characterization}

HPLC-UV characterization and quantification were carried out according to a reported method (Zeb 2015). Briefly, 1-g powdered sample for cell cultures was added to water and methanol in equal ratio, and the mixture was subject to heating in a water bath at $70{ }^{\circ} \mathrm{C}$ for $1 \mathrm{~h}$. The mixture was then spun for $10 \mathrm{~min}$ at $4000 \mathrm{rpm}$ and was ultimately filtered (Whatman filter paper $11 \mu \mathrm{m}$ ).

The Agilent-1260 infinity High-performance liquid chromatography (HPLC) system was employed to identify and quantify phenolic compounds. The HPLC system's essential parts were a quaternary pump, an auto-sampler, a degasser, an ultraviolet array detector (UVAD), and a C18 column (Agilent-Zorbax-Eclipse column). The solution (B and $\mathrm{C}$ ) gradient was such that solvent $\mathrm{B}$ was a mixture of acetic acid: methanol: deionized water (20: 100: $180 \mathrm{v} / \mathrm{v})$, and solvent $\mathrm{C}$ was a mixture of acetic acid deionized water: methanol (20: 80:900) v/v. The solvents were provided as a gradient such that they started and gradually decreased the solvent in concentration. Solvent B was given in volume $100,85,50$, and $30 \%$ at $0,5,20$, and 25 min, finally giving way to $100 \%$ solvent C from $30 \mathrm{~min}$ onwards till $40 \mathrm{~min}$. Elution was recorded after $25 \mathrm{~min}$. The ultraviolet array detector (UVAD) was set at wavelength $320 \mathrm{~nm}$ to analyze phenolic compounds, and the chromatograms were recorded from 190 to $500 \mathrm{~nm}$. Phenolic compounds mentioned in HPLC Table were used as the standards for comparing their types and quantities of these metabolites among control and treatments.

The quantification of antioxidants was measured by formula:

$C x=\frac{A x \times C s(\mu g / m l) \times V(m l)}{A s \times \text { Sample }(w t . i n g)}$

where $A x=$ Sample peak area, $A s=$ Standard peak area, $C x=$ Sample concentration and $C s=$ Standard concentration $(0.09 \mu \mathrm{g} / \mathrm{ml})$.

\section{Statistical analysis}

We have performed the experiments for this study according to a completely randomized design. The experiments were repeated twice, with three replicated during each experiment for statistical accuracy. We used linear regression analysis to determine the significant mean difference $(\mathrm{P}<0.05)$. Similarly, we used the Pearson Correlation Coefficient (Pearson's r) to derive relationship between antioxidant activity and the 


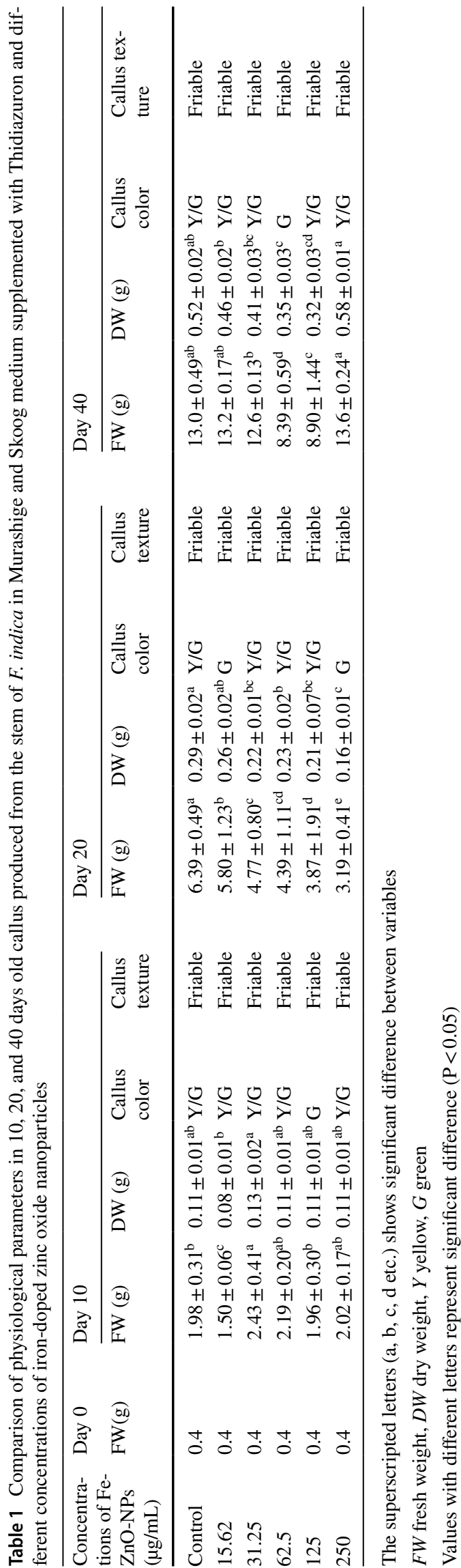

production of phenolic compounds. The program used for statistical analysis was SPSS version 20. We used Origin 8.5 pro for the preparation of all the figures.

\section{Results and discussion}

\section{Growth and morphological attributes of callus cultures}

Callus was obtained using healthy stem cutting as explant (5 mm approx.) from a 30-day old plantlet (Fig. 1). Approximately $400 \mathrm{mg}$ callus was sub-cultured in $35 \mathrm{~mL}$ MS media with TDZ $(1.0 \mathrm{mg} / \mathrm{mL})$, a plant growth regulator, and $\mathrm{Fe}$ $\mathrm{ZnO}-\mathrm{NPs}$ as elicitors. The callus response was slow in the initial stages, but it improved with time. Fresh green and friable callus were obtained on days 10 and 20, while yellowish-green callus after 40 days of a culture grown under different concentrations of Fe-ZnO-NPs compared to control (Fig. 1). The interactions of NPs with the callus changed their color from light green to yellowish-green because metallic nanoparticles, including metal oxides and pure metals, have been recently studied to affect various plants' progress. Various developmental constraints verified in plants, such as propagations, development, biomass-accumulation, and biochemical events, have been observed in response to these metallic NPs in diverse plants.

The fresh weight of the culture was measured on days $0,10,20$, and 40 . The results showed that at day 10 , callus with the highest FW $(2.43 \pm 0.41 \mathrm{~g})$ was observed in the group supplemented with $31.25 \mu \mathrm{g} / \mathrm{mL} \mathrm{Fe-ZnO-NPs,} \mathrm{while}$ the lowest FW $(1.50 \pm 0.06 \mathrm{~g})$ was observed in the group supplemented with $15.62 \mu \mathrm{g} / \mathrm{mL}$ Fe-ZnO-NPs as compared to control group $(1.98 \pm 0.31 \mathrm{~g})$. On day 20 , the control group exhibited the highest FW $(6.39 \pm 0.49 \mathrm{~g})$ compared to the different concentrations of Fe-ZnO-NPs (Table 1). On day 20 , the lowest FW $(3.19 \pm 0.41 \mathrm{~g})$ was observed in the group grown under the effect of $250 \mu \mathrm{g} / \mathrm{mL}$ Fe-ZnO-NPs. Overall, the callus biomass increased with time as shown in the growth curve (Fig. 2). In terms of time, the callus seemed to be retarded by the application of nanoparticles during initial days. However, after 40 days, most probably due to adjustments to the nanoparticles, highest biomass was recorded in treatment groups. However, with increasing the concentration of $\mathrm{Fe}-\mathrm{ZnO}-\mathrm{NPs}$, a decrease in the $\mathrm{FW}$ of callus was observed such that the FW was $5.80 \pm 1.23$, $4.77 \pm 0.80,4.39 \pm 1.11$, and $3.87 \pm 1.91 \mathrm{~g}$ at a concentration of $15.62,31.25,62.5$, and $125 \mu \mathrm{g} / \mathrm{mL}$, respectively (Table 1). The reason for this trend seems to be because high $\mathrm{Zn}$ concentrations are toxic to the plants. For instance, Broadley et al. (2007) showed that $\mathrm{Zn}$ phytotoxicity becomes apparent at a concentration higher than $300 \mathrm{mg} / \mathrm{kg}$ in leaves. However, in a nano form, Zinc (aided by iron) affects biomass 
accumulation positively once the callus cells get enough time to get acclimatized. Similarly, Mosavat et al. (2019) reported that the application of Zinc oxide nanoparticles results in a significant increase in fresh weight of callus different Thymus species and Zataria multiflora. Our results show that 40 days, the highest FW $(13.6 \pm 0.24 \mathrm{~g})$ was observed in callus grown under the effect of $250 \mu \mathrm{g} /$ $\mathrm{mL} \mathrm{Fe}-\mathrm{ZnO}-\mathrm{NPs}$, while the lowest FW $(8.39 \pm 0.59 \mathrm{~g})$ was observed in $62.5 \mu \mathrm{g} / \mathrm{mL}$ as compared to the control group where the FW was $(13.0 \pm 0.49 \mathrm{~g})$. When dry weight was recorded, after ten days, the highest DW $(0.13 \pm 0.02 \mathrm{~g})$ was recorded in callus grown under the effect of $31.25 \mu \mathrm{g} / \mathrm{mL}$ Fe-ZnO-NPs.

In comparison, the lowest DW after ten days $(0.08 \pm 0.01 \mathrm{~g})$ was observed in callus grown in $15.62 \mu \mathrm{g} /$ $\mathrm{mL} \mathrm{Fe}-\mathrm{ZnO}-\mathrm{NPs}$ compared to the control group (DW $=0.11 \pm 0.31 \mathrm{~g}$ ). Similarly, on day 20 , the highest DW $(0.29 \pm 0.02 \mathrm{~g})$ was recorded in the control group compared to the different concentrations of Fe-ZnO-NPs. It was observed that on day 20, the DW decreased with increasing the concentrations of Fe-ZnO-NPs in the media (Table 1). It seems like the cells of $F$. indica got acclimatized to the application of Fe-ZnO-NPs with time. It is evident from the results that the highest FW and DW were recorded because of supplementation of $250 \mu \mathrm{g} / \mathrm{mL} \mathrm{Fe}$-ZnO-NPs. Metallic nanoparticles have been observed to impact plants' various developmental processes, such as propagations, development, biomass-accumulation, and biochemical events. Different impacts of NPs in plants range from helpful to destructive and from deceptive physiological to veiled biochemical deviations (Khan et al. 2019). Fe-ZnO-NPs are inorganic nanoparticles that offer more significant material properties with functional flexibility [9]. There are numerous methods to change the dielectric and other metal oxide nanostructure properties in doping. In this study, Fe-ZnONPs seem to act as a multi-pronged tool having the nutrient supplementation capability in the form of essential supplements like Iron (Fe) and Zinc (Zn) (Xie et al. 2019).

Conversely, these are provided as nanomaterial with an enhanced delivery to cells where they play their crucial role in growth and development as micronutrients (Cabot et al. 2019). For instance, studies have shown that these NPs improved germination and rate of growth. The NPs may also prove poisonous for the plants by increasing ROS production and changing the plants' genetic and anatomical performances. For instance, Zinc oxide nanoparticles have been observed to boost progress in terms of rate of seed germination, seedling potency, initial flowering, and improved chlorophyll content in different plants such as green pea, peanut, cucumber, and Soybean (Yusefi-Tanha et al. 2020).

\section{Phytochemical analysis of callus under Fe-ZnO-NPs stress}

\section{Production of total phenolic content}

The TPC at days 10, 20, and 40 of the callus subcultures was determined. The highest TPC $(268.79 \pm 11.44 \mu \mathrm{g} \mathrm{GAE} / \mathrm{g}$ of DW) was produced in 40-days old callus cultures when supplemented with $125 \mu \mathrm{g} / \mathrm{mL}$ Fe-ZnO-NPs. Generally, at day 10 , TPC was the high in quantity $(239.56 \pm 3.46 \mu \mathrm{g}$ GAE/g of DW) when the callus cultures were provided with $15.62 \mu \mathrm{g} / \mathrm{mL}$ Fe-ZnO-NPs as compared to the control group ( $\mathrm{TPC}=230.44 \pm 3.46 \mu \mathrm{g} \mathrm{GAE} / \mathrm{g}$ of DW). While the lowest TPC $(178.34 \pm 6.54 \mu \mathrm{g} \mathrm{GAE} / \mathrm{g}$ of DW) was recorded in the ten-day-old callus when supplemented with $250 \mu \mathrm{g} / \mathrm{mL}$ Fe-ZnO-NPs. In 10-day-old callus, the TPC decreased compared to control when the media had higher than $15.62 \mu \mathrm{g} /$ $\mathrm{mL} \mathrm{Fe}-\mathrm{ZnO}-\mathrm{NPs}$ (Fig. 3). A more inadequate response in terms of TPC with increasing concentration of Fe-ZnO-NPs seems to be because of the cells' inability to cope with the excess nanomaterial in the media. This response correlates with the lower response of biomass accumulation at day 10 (Table 1). This lower biomass might be because chemically synthesized nanomaterial proves toxic to cells, making them unable to cope with them. The NPs may also prove poisonous for the plants by increasing ROS production and changing the plants' genetic and anatomical performances (Kim et al. 2017). DNA breakage was also detected due to $\mathrm{ZnO}$ NPs toxicity in Allium cepa (Rastogi et al. 2017). However,
Fig. 1 Comparative morphology of $F$. indica callus culture grown in (a) $\mathrm{Fe}-\mathrm{ZnO}-\mathrm{NPs}$ supplemented medium and (b) without Fe-ZnO-NPs
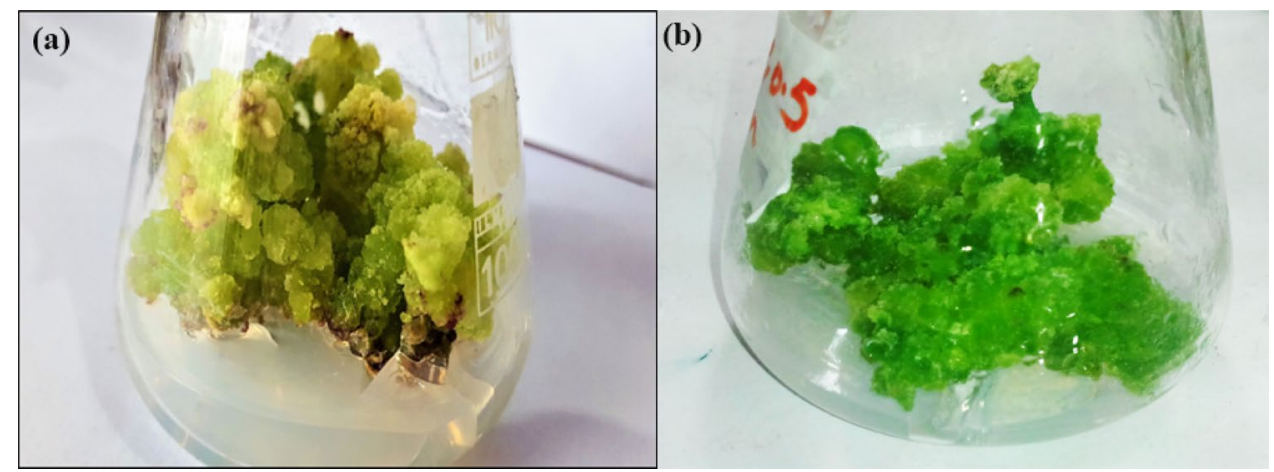
Table 2 High performance liquid chromatography based quantification of phenolic compounds triggered as a result of iron-doped zinc oxide nanoparticles in cell cultures of Fagonia indica

\begin{tabular}{|c|c|c|c|c|c|c|c|c|}
\hline $\begin{array}{l}\text { Sample } \\
\text { extract }\end{array}$ & No. of peak & $\begin{array}{l}\text { Retention } \\
\text { time (min) }\end{array}$ & $\begin{array}{l}\text { Phenolic } \\
\text { compounds } \\
\text { identity }\end{array}$ & $\begin{array}{l}\text { HPLC-UV } \\
\lambda \max (\mathrm{nm})\end{array}$ & $\begin{array}{l}\text { Peak area of } \\
\text { sample }\end{array}$ & $\begin{array}{l}\text { Peak area of } \\
\text { standard }\end{array}$ & $\begin{array}{l}\text { Concentration } \\
(\mu \mathrm{g} / \mathrm{ml})\end{array}$ & $\begin{array}{l}\text { Identification } \\
\text { reference }\end{array}$ \\
\hline \multirow[t]{7}{*}{ Control } & 1 & 2.6 & Malic acid & 320 & 74.81 & 40.32 & $18.56^{\mathrm{e}}$ & $\begin{array}{r}\text { Reference } \\
\text { standard }\end{array}$ \\
\hline & 2 & 12.4 & Morin & 320 & 32.90 & 20.0 & $16.45^{\mathrm{f}}$ & $\begin{array}{r}\text { Reference } \\
\text { standard }\end{array}$ \\
\hline & 3 & 16.5 & Ellagic acid & 320 & 97.98 & 319.24 & $3.07^{\mathrm{i}}$ & $\begin{array}{r}\text { Reference } \\
\text { standard }\end{array}$ \\
\hline & 4 & 20.5 & $\begin{array}{r}\text { Catechin } \\
\text { hydrate }\end{array}$ & 320 & 385.32 & 78.0 & $49.4^{\mathrm{c}}$ & $\begin{array}{l}\text { Reference } \\
\text { standard }\end{array}$ \\
\hline & 5 & 22.7 & Rutin & 320 & 156.79 & 2241.2 & $0.69^{\mathrm{k}}$ & $\begin{array}{r}\text { Reference } \\
\text { standard }\end{array}$ \\
\hline & 6 & 27.7 & Pyrogallol & 320 & 1878.23 & 1.014 & $18,522.97^{\mathrm{bc}}$ & $\begin{array}{r}\text { Reference } \\
\text { standard }\end{array}$ \\
\hline & 7 & 30.2 & Mandelic acid & 320 & 20.96 & 72.0 & $2.91^{\mathrm{j}}$ & $\begin{array}{r}\text { Reference } \\
\text { standard }\end{array}$ \\
\hline \multirow[t]{7}{*}{$40-1$} & 1 & 2.6 & Malic acid & 320 & 96.32 & 40.32 & $23.90^{\mathrm{de}}$ & $\begin{array}{r}\text { Reference } \\
\text { standard }\end{array}$ \\
\hline & 2 & 8.3 & $\begin{array}{l}\text { Epigallocat- } \\
\text { echin gallate }\end{array}$ & 320 & 18.27 & 72.6 & $2.52^{j}$ & $\begin{array}{r}\text { Reference } \\
\text { standard }\end{array}$ \\
\hline & 3 & 12.4 & Morin & 320 & 55.11 & 20.0 & $27.55^{\mathrm{d}}$ & $\begin{array}{r}\text { Reference } \\
\text { standard }\end{array}$ \\
\hline & 4 & 16.5 & Ellagic acid & 320 & 237.34 & 319.24 & $7.43^{\mathrm{g}}$ & $\begin{array}{r}\text { Reference } \\
\text { standard }\end{array}$ \\
\hline & 5 & 20.5 & $\begin{array}{r}\text { Catechin } \\
\text { hydrate }\end{array}$ & 320 & 56.04 & 78.0 & $7.18^{\mathrm{g}}$ & $\begin{array}{r}\text { Reference } \\
\text { standard }\end{array}$ \\
\hline & 6 & 27.7 & Pyrogallol & 320 & 1968.24 & 1.014 & $19,410.65^{\mathrm{a}}$ & $\begin{array}{r}\text { Reference } \\
\text { standard }\end{array}$ \\
\hline & 7 & 30.2 & Mandelic acid & 320 & 129.91 & 72.0 & $18.04^{\mathrm{e}}$ & $\begin{array}{r}\text { Reference } \\
\text { standard }\end{array}$ \\
\hline \multirow[t]{7}{*}{$40-2$} & 1 & 2.6 & Malic acid & 320 & 25.90 & 40.32 & $6.43^{\mathrm{h}}$ & $\begin{array}{r}\text { Reference } \\
\text { standard }\end{array}$ \\
\hline & 2 & 8.3 & $\begin{array}{l}\text { Epigallocat- } \\
\text { echin gallate }\end{array}$ & 320 & 48.33 & 72.6 & $6.65^{\mathrm{h}}$ & $\begin{array}{r}\text { Reference } \\
\text { standard }\end{array}$ \\
\hline & 3 & 12.4 & Morin & 320 & 85.66 & 20.0 & $42.83^{\mathrm{c}}$ & $\begin{array}{r}\text { Reference } \\
\text { standard }\end{array}$ \\
\hline & 4 & 16.5 & Ellagic acid & 320 & 233.46 & 319.24 & $7.31^{\mathrm{g}}$ & $\begin{array}{r}\text { Reference } \\
\text { standard }\end{array}$ \\
\hline & 5 & 20.5 & $\begin{array}{r}\text { Catechin } \\
\text { hydrate }\end{array}$ & 320 & 346.95 & 78.0 & $44.48^{\mathrm{c}}$ & $\begin{array}{r}\text { Reference } \\
\text { standard }\end{array}$ \\
\hline & 6 & 27.7 & Pyrogallol & 320 & 1885.61 & 1.014 & $18,595.75^{\mathrm{b}}$ & $\begin{array}{l}\text { Reference } \\
\text { standard }\end{array}$ \\
\hline & 7 & 30.2 & Mandelic acid & 320 & 19.41 & 72.0 & $2.69^{j}$ & $\begin{array}{r}\text { Reference } \\
\text { standard }\end{array}$ \\
\hline
\end{tabular}

40-1 cell cultures supplemented with $31.5 \mu \mathrm{g} / \mathrm{ml} \mathrm{Fe-ZnO-NPs} \mathrm{for} 40$ days, $40-2$ cell cultures supplemented with $250 \mu \mathrm{g} / \mathrm{ml} \mathrm{Fe-ZnO-NPs} \mathrm{for}$ 40 days

The superscripted letters $(\mathrm{a}, \mathrm{b}, \mathrm{c}, \mathrm{d}$ etc.) shows significant difference between variables. Values with different letters represent significant difference $(\mathrm{P}<0.05)$ 


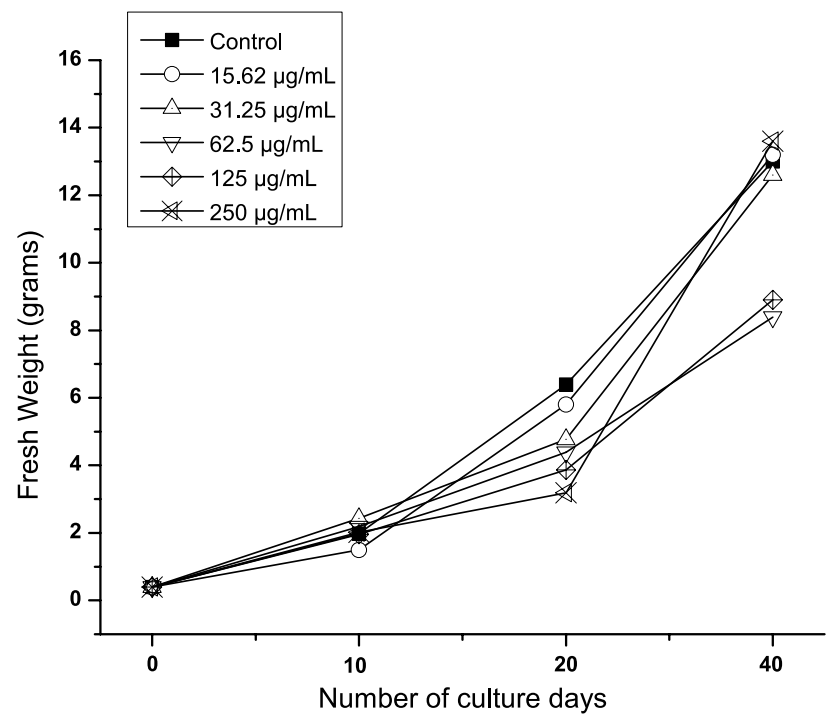

Fig. 2 Growth curve for the callus biomass accumulation in response to different concentrations of Fe-ZnO-NPs

increasing the concentration of nanoparticles up to $125 \mu \mathrm{g} /$ $\mathrm{mL}$ increased TPC compared to the control group. On day 20 , the TPC was highest $(232.84 \pm 7.85 \mu \mathrm{g} \mathrm{GAE} / \mathrm{g}$ of DW) when the media was supplemented with $62.5 \mu \mathrm{g} / \mathrm{mL} \mathrm{Fe-}$ ZnO-NPs. In comparison, the TPC observed in the control group after 20 days were $225.89 \pm 12.67 \mu \mathrm{g}$ GAE/g of DW. A higher TPC concentration was produced in numerous plant species in response to different environmental strains (Hussain et al. 2019). For instance, different Thymus species and Zataria multiflora produced important secondary

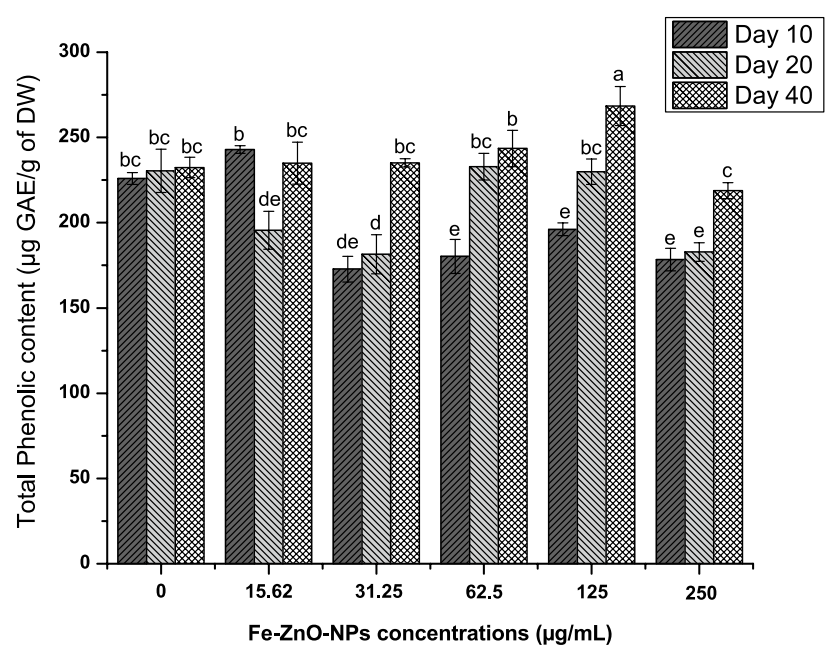

Fig. 3 Effects of different concentration of Fe-ZnO-NPs on day 10, 20 and 40 on total phenolic content accumulation in callus cultures of $F$. indica. The superscripted letters (a, b, c, d etc.) shows significant difference between variables; Values with different letters represent significant difference $(\mathrm{P}<0.05)$

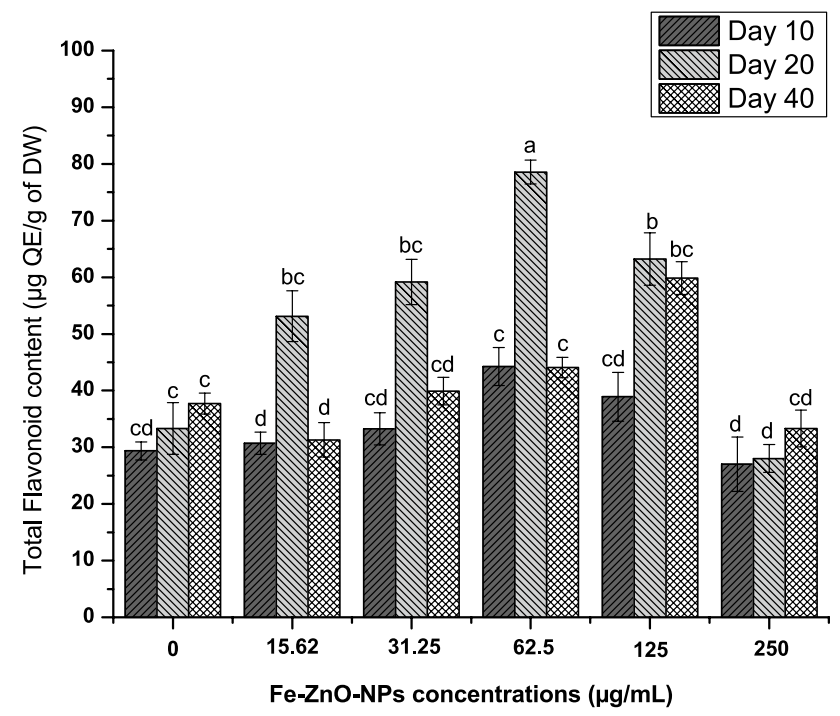

Fig. 4 Effects of different concentration of Fe-ZnO-NPs on day 10, 20 and 40 on TFC in callus cultures of $F$. indica. The superscripted letters ( $\mathrm{a}, \mathrm{b}, \mathrm{c}, \mathrm{d}$ etc.) shows significant difference between variables; values with different letters represent significant difference $(\mathrm{P}<0.05)$

metabolites when their callus cultures when supplemented with Zinc oxide nanoparticles (Mosavat et al. 2019).

\section{Production of flavonoids in response to Fe-ZnO-NPs supplementation}

The TFC in 10, 20, and 40 days of callus establishment was recorded. The highest TFC $(78.56 \pm 0.12 \mu \mathrm{g} \mathrm{QE} / \mathrm{g}$ of DW) was recorded on day 20 was recorded in callus derived from media supplemented with $62.5 \mu \mathrm{g} / \mathrm{mL}$ FeZnO-NPs. Generally, at day 10 , the TFC was high in quantity $(44.26 \pm 3.35 \mu \mathrm{g}$ QE/g of DW) in media with $62.5 \mu \mathrm{g} /$ $\mathrm{mL}$ Fe-ZnO-NPs, while the lowest $(27.01 \pm 5.80 \mu \mathrm{g} \mathrm{QE} / \mathrm{g}$ of DW) when the concentration of Fe-ZnO-NPs in media reached $250 \mu \mathrm{g} / \mathrm{mL}$ compared to the control group with $\mathrm{TFC}=33.30 \pm 1.59 \mu \mathrm{g} \mathrm{QE} / \mathrm{g}$ of DW. Similarly, for the other concentrations, the TFC increasing with increasing the concentrations of Fe-ZnO-NPs in the media. TFC derived from callus grown with $15.62,31.25$, and $125 \mu \mathrm{g} / \mathrm{mL} \mathrm{Fe}-\mathrm{ZnO}-$ NPs produced 53.11 $\pm 4.47,59.16 \pm 3.98$, and $63.20 \mu \mathrm{g} \mathrm{QE} / \mathrm{g}$ of DW, respectively as compared to the control group with $\mathrm{TFC}=29.36 \pm 4.56 \mu \mathrm{g}$ QE/g of DW. More specifically, the TFC increased with increasing concentration of Fe-ZnONPs up to $62.5 \mu \mathrm{g} / \mathrm{mL}$. At higher concentrations, the production of TFC declined. With $125 \mu \mathrm{g} / \mathrm{mL}$ of Fe-ZnO-NPs, the highest TFC recorded was $63.20 \mu \mathrm{g}$ QE/g of DW in 20 days old callus followed by $59.86 \pm 2.89 \mu \mathrm{g}$ QE/g of DW in 40 days old callus (Fig. 4). In this study, it was observed that $\mathrm{Fe}-\mathrm{ZnO}-\mathrm{NPs}$, in higher concentrations, caused toxicity to callus. In low concentration, it induces better impacts on the production of secondary metabolites in callus culture. 
The NPs in higher concentrations were observed to enter the plant and plasma membrane cell wall and network with the various plant processes (Rastogi et al. 2017).

In general, essential micronutrients aid plant health by directly activating enzymes that produce defense metabolites like flavonoids. Although no specific mechanism has been established, Zinc plays a vital role in plant immune responses (Cabot et al. 2019). Besides Zn, Fe plays a crucial role in mediating an oxidative burst via the production of $\mathrm{H}_{2} \mathrm{O}_{2}$ (Greenshields et al. 2007), which leads to the production of scavenging secondary metabolites. This seems to be one reason for triggering the phenolics and flavonoids produced in callus cultures of $F$. indica by $\mathrm{Fe}-\mathrm{ZnO}$-nanomaterials loaded with both $\mathrm{Fe}$ and $\mathrm{Zn}$.

\section{Antioxidant defense system triggered by Fe-ZnO-NPs supplementation}

The antioxidant activities were determined according to the \% DPPH scavenging capacity of 10-, 20- and 40-days old callus. On day 10 , the highest antioxidant activity was recorded $(67.78 \%)$ in callus obtained from media with $31.25 \mu \mathrm{g} / \mathrm{mL}$ Fe-ZnO-NPs. The lowest activity (49.01\%) was produced in the control group (Fig. 5). Furthermore, FRSA of $54.34,56.86,51.51$, and $49.07 \%$ was observed in callus derived from 15.62, 62.5, 125, and $250 \mu \mathrm{g} / \mathrm{mL} \mathrm{Fe-ZnO-NPs,}$ respectively. On day 20 , the highest antioxidants activity (75.27\%) was produced in callus obtained at $15.62 \mu \mathrm{g} / \mathrm{mL}$ Fe-ZnO-NPs. In comparison, the lowest activity (58.83\%) was produced in callus derived from media with $250 \mu \mathrm{g} / \mathrm{mL}$ Fe-ZnO-NPs. Furthermore, there was a decrease in FRSA

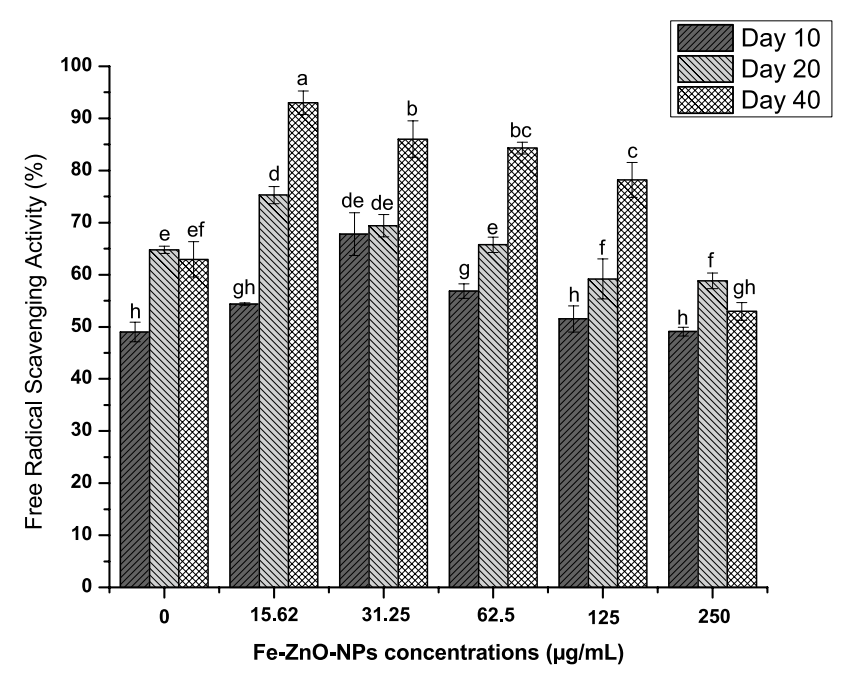

Fig. 5 Effects of different concentration of Fe-ZnO-NPs on day 10, 20 and 40 on free radical scavenging activity in callus cultures of $F$. indica. The superscripted letters (a, b, c, d etc.) shows significant difference between variables; Values with different letters represent significant difference $(\mathrm{P}<0.05)$ with increasing nanoparticle concentration in the media such that $69.41,65.73$, and 59.18\% FRSA was recorded in callus grown at $31.25,62.5125 \mu \mathrm{g} / \mathrm{mL}$ Fe-ZnO-NPs, respectively compared to the control group with $64.77 \%$ activity. On day 40, the highest antioxidant activity $(93.02 \%)$ was observed in callus derived from media having $15.62 \mu \mathrm{g} / \mathrm{mL} \mathrm{Fe}-\mathrm{ZnO}$ NPs. In comparison, the lowest activity $(52.95 \%)$ was recorded in $125 \mu \mathrm{g} / \mathrm{mL} \mathrm{Fe}-\mathrm{ZnO}-\mathrm{NPs}$. Fe and $\mathrm{Zn}$ are showed to induce ROS-dependent antioxidant defense mechanisms. Metal accumulation in plant cells triggers the antioxidant defense system by activating superoxide dismutase, catalase, or other detoxification-related enzymes such as acid phosphatase (ACP) and alkaline phosphatase (AKP) (Khan et al. 2019). Besides, phenolic and flavonoids are recognized to have antioxidant activity, and these compounds of the extract are responsible for these activities (Rebaya et al. 2014). Plants defend themselves by scavenging free radicals with phytochemicals, which act as antioxidants. Another essential and recently defined factor that supports the $\mathrm{Zn}$-mediated defense of plant cells is Zinc finger protein (ZFP). ZFPs play a crucial role in plant growth, phytohormone response, and stress tolerance (Noman et al. 2019).

The importance of Fe-ZnO-NPs is further evident in their role in enhancing the total antioxidants capacity of cells of $F$. indica. The TAC in 10, 20, and 40 days after callus subculture was recorded. On day 10, the highest TAC $(327.96 \pm 7.46 \mu \mathrm{g}$ AAE/g of DW) was recorded in callus grown under the effect of $125 \mu \mathrm{g} / \mathrm{mL}$ Fe-ZnO-NPs, while the lowest TAC $(157.57 \pm 1.33 \mu \mathrm{g}$ AAE/g of DW) was recorded in callus supplemented with $250 \mu \mathrm{g} / \mathrm{mL} \mathrm{Fe}-\mathrm{ZnO}-\mathrm{NPs}$. A TAC of $228.06 \pm 7.60,238.15 \pm 8.77$, and $230.07 \pm 8.99 \mu \mathrm{g}$ AAE/g of DW was seen in 15.62, 31.25, $62.5 \mu \mathrm{g} / \mathrm{mL} \mathrm{Fe-}$ $\mathrm{ZnO}-\mathrm{NPs}$, respectively compared to the control group $(\mathrm{TAC}=216.23 \pm 9.61 \mu \mathrm{g} \mathrm{AAE} / \mathrm{g}$ of DW). On day 10 , the TAC increased compared to control at 15.62, 31.25, 62.5, and $125 \mu \mathrm{g} / \mathrm{mL}$ Fe-ZnO-NPs, respectively. However, there was no significant difference in TAC at the medium concentrations of Fe-ZnO-NPs. On day 20, the highest TAC, i.e., $313.92 \pm 2.10 \mu \mathrm{g} \mathrm{AAE} / \mathrm{g}$ of DW, was recorded in callus grown with $62.5 \mu \mathrm{g} / \mathrm{mL} \mathrm{Fe}-\mathrm{ZnO}-\mathrm{NPs}$, while the lowest TAC (199.64 $\pm 8.17 \mu \mathrm{g}$ AAE/g of DW) was recorded from callus grown on media with $31.25 \mu \mathrm{g} / \mathrm{mL}$ Fe-ZnO-NPs as compared to the control group with TAC $230.84 \pm 6.41 \mu \mathrm{g}$ AAE/g of DW (Fig. 6). At day 40, the highest TAC $(390.74 \pm 5.56 \mu \mathrm{g}$ AAE/g of DW) was observed in callus derived from $125 \mu \mathrm{g} / \mathrm{mL}$ Fe-ZnO-NPs containing media, while the lowest TAC, i.e., $241.35 \pm 6.97 \mu \mathrm{g} \mathrm{AAE} / \mathrm{g}$ of DW was recorded in control. Further, TAC $=247.38 \pm 2.71$, $265.14 \pm 7.29,246.51 \pm 3.54$, and $317 \pm 10.10 \mu \mathrm{g}$ AAE $/ \mathrm{g}$ of DW was recorded in callus derived from media with $15.62,31.25,62.5$, and $250 \mu \mathrm{g} / \mathrm{mL} \mathrm{Fe}-\mathrm{ZnO}-\mathrm{NPs}$, respectively. On day 40 , the TAC increased with the increasing concentration of Fe-ZnO-NPs. The phospho-molybdenum 


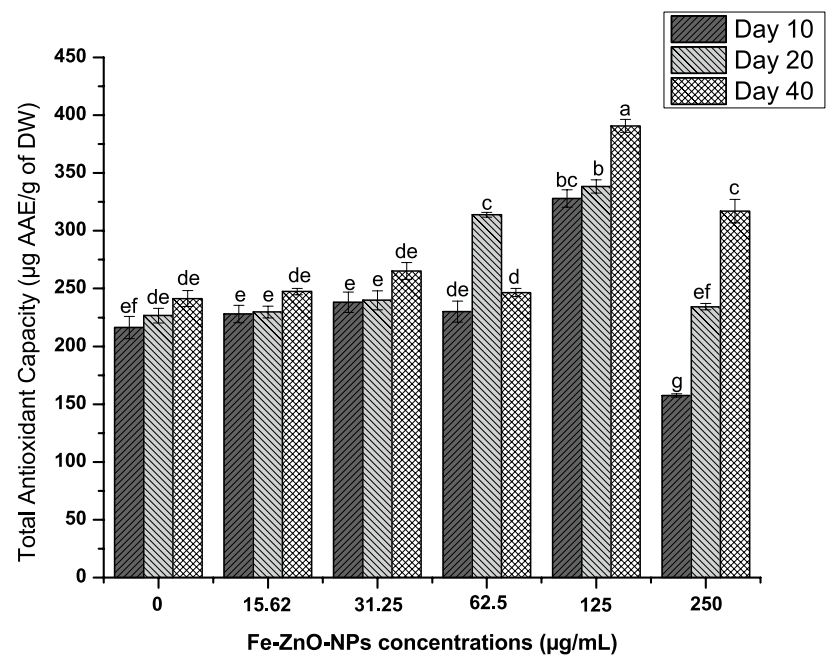

Fig. 6 Effect of different concentrations of Fe-ZnO-NPs on day 10, 20 and 40 on total antioxidant capacity in callus cultures of $F$. indica. The superscripted letters (a, b, c, d etc.) shows significant difference between variables; Values with different letters represent significant difference $(\mathrm{P}<0.05)$

quantitative technique was used to study the TAC changes of the $F$. indica callus under Fe-ZnO-NPs concentrations. The results indicate that $\mathrm{Fe}-\mathrm{ZnO}-\mathrm{NPs}$ supplementation increases the TAC. These results demonstrated a significant increase in callus antioxidant activity in response to in vitro $\mathrm{Fe}-\mathrm{ZnO}$ NPs supplementation. The role of Fe-ZnO-NPs as abiotic elicitors in affecting the morphology and physiology of callus and production of secondary metabolites from the callus of $F$. indica is a new frontier in abiotic stress elicitation. These nanoparticles execute oxidative stress to the callus tissues, activating their metabolism and enhancing all antioxidant activities. However, the callus' growth and antioxidant activities are alleviated because higher Fe-ZnO-NPs cause lethality to plant ultimately (Javed et al. 2018).

\section{HPLC analysis of Fe-ZnO-NPs based elicited cultures}

HPLC analysis of our samples revealed that Fe-ZnO-NPs supplementation had a marked effect on the phenolic compounds produced in cell cultures of $F$. indica. A total of seven antioxidant phytochemicals/compounds were identified in plant extracts (Table 2).

There was variation in terms of quantity and the uniqueness of secondary metabolites produced in cell cultures triggered by Fe-ZnO-NPs in media (Figure S1-S3). For instance, the control group, i.e., cell cultures devoid of Fe-ZnO-NPs, produced Malic acid in quantities equivalent to $18.56 \mu \mathrm{g} / \mathrm{ml}$, which was enhanced to $23.90 \mu \mathrm{g} / \mathrm{ml}$ in cell culture extract supplemented with $31.25 \mu \mathrm{g} / \mathrm{ml} \mathrm{Fe-ZnO-NPs.} \mathrm{Interest-}$ ingly, the increase in Fe-ZnO-NPs concentration $(250 \mu \mathrm{g} /$ $\mathrm{ml}$ ) caused a decline in malic acid production to $6.43 \mu \mathrm{g} / \mathrm{ml}$.
Similarly, the quantities of Ellagic acid, Morin, Mandelic acid, and Pyrogallol were enhanced in Fe-ZnO-NPs supplemented cell cultures compared to control (Table 2). Furthermore, it has been observed that Fe-ZnO-NPs $(250 \mu \mathrm{g} / \mathrm{ml})$ triggered the production of Epigallocatechin gallate $(6.65 \mu \mathrm{g} / \mathrm{ml})$, which was absent in the control group. One of the reasons for this could be that Iron $(\mathrm{Fe})$ is a transition metal that forms chelates and complexes with phenolic plant secondary metabolites. It has been observed that epigallocatechin gallate acts as a robust Iron chelator (Md Nesran et al. 2020). In our case, iron supplementation in the form of $\mathrm{Fe}-\mathrm{ZnO}$-NPs might have triggered the production of enhanced quantities of this compound to reduce the toxic effects of Iron and Zinc given in excess amounts $(250 \mu \mathrm{g} / \mathrm{ml})$. Epigallocatechin gallate is a Catechin. The results observed above could be validated through another exciting observation that the amount of Catechin hydrate reduced a bit in Fe- $\mathrm{ZnO}-\mathrm{NPs}$ based samples. This hints toward the possibility that Catechin hydrate might have contributed to an ester's formation with gallic acid, i.e., Epigallocatechin gallate.

On the other hand, the control, i.e., callus cultures devoid of Fe-ZnO-NPs, produced Rutin $(0.69 \mu \mathrm{g} / \mathrm{ml})$ which was not present in cell cultures supplemented with Fe-ZnO-NPs. The quantification and identification of each phenolic compound with its particular peak position and retention time $(\mathrm{Rt})$ are presented in Table 2 . The representative chromatograms are given in the supplementary information (ES1-3).

\section{Conclusion}

Conclusively, Fe-ZnO-NPs proved to be very efficient regulators of physiology and biochemical parameters of $F$. indica callus cultures. These results showed that Fe- $\mathrm{ZnO}-$ NPs could prove as a vital elicitor of plant cell metabolism. The Fe-ZnO-NPs elicited callus cultures exhibited higher levels of phenolics, flavonoids, and antioxidants activity. The doped form of nanomaterials could prove as a new frontier in applying different strategies for producing novel secondary metabolites in the cells of medicinal plants. The findings of the current study suggest that nanoparticles, especially $\mathrm{Fe}-\mathrm{ZnO}-\mathrm{NPs}$, possess a strong potential to enhance biomass production and yield of total phenolic, total flavonoids, antioxidants activity, and total antioxidant capacity compounds in callus cultures of $F$. indica.

Supplementary Information The online version contains supplementary material available at https://doi.org/10.1007/s11240-021-02123-1. 
Acknowledgements The authors acknowledge the role of the Department of Biotechnology, University of Malakand, in providing resources to perform this research.

Funding Part of the research supplies for the project's execution were provided through the Higher Education Commission research project, NRPU 6649 and International Foundation for Science funded research project IFS F 6455-1.

\section{Declarations}

Conflict of interest The authors declare that they have no conflict of interest.

\section{References}

Alharby HF, Metwali EM, Fuller MP, Aldhebiani AY (2016) Impact of application of zinc oxide nanoparticles on callus induction, plant regeneration, element content and antioxidant enzyme activity in tomato (Solanum lycopersicum Mill.) under salt stress. Arch Biol Sci 68(4):723-735

Broadley MR, White PJ, Hammond JP, Zelko I, Lux A (2007) Zinc in plants. New Phytol 173(4):677-702. https://doi.org/10.1111/j. 1469-8137.2007.01996.x

Cabot C, Martos S, Llugany M, Gallego B, Tolrà R, Poschenrieder C (2019) A role for zinc in plant defense against pathogens and herbivores. Front Plant Sci. https://doi.org/10.3389/fpls.2019.01171

Eman AA, Gehan HA, Yassin M, Mohamed S (2010) Chemical composition and antibacterial activity studies on callus of Fagonia arabica $\mathrm{L}$. Acad Arena 2(12):91-106

Greenshields DL, Liu G, Wei Y (2007) Roles of iron in plant defence and fungal virulence. Plant Signal Behav 2(4):300-302. https:// doi.org/10.4161/psb.2.4.4042

Hassan MM, Ahmed AS, Chaman M, Khan W, Naqvi A, Azam A (2012) Structural and frequency dependent dielectric properties of $\mathrm{Fe} 3+$ doped $\mathrm{ZnO}$ nanoparticles. Mater Res Bull 47(12):3952-3958

Hussain F, Hadi F, Akbar F (2019) Magnesium oxide nanoparticles and thidiazuron enhance lead phytoaccumulation and antioxidative response in Raphanus sativus L. Environ Sci Pollut Res 26:1-15

Javed R, Yucesan B, Zia M, Gurel E (2018) Elicitation of secondary metabolites in callus cultures of Stevia rebaudiana Bertoni grown under $\mathrm{ZnO}$ and $\mathrm{CuO}$ nanoparticles stress. Sugar Tech 20(2):194-201

Khan T, Abbasi BH, Khan MA, Shinwari ZK (2016) Differential effects of thidiazuron on production of anticancer phenolic compounds in callus cultures of Fagonia indica. Appl Biochem Biotechnol 179(1):46-58

Khan MA, Khan T, Riaz MS, Ullah N, Ali H, Nadhman A (2019) Plant cell nanomaterials interaction: growth, physiology and secondary metabolism. Comprehensive analytical chemistry, vol 84. Elsevier, Amsterdam, pp 23-54

Khan MA, Ali A, Mohammad S, Ali H, Khan T, Jan A, Ahmad P (2020a) Iron nano modulated growth and biosynthesis of steviol glycosides in Stevia rebaudiana. Plant Cell Tiss Organ Cult 143(1):121-130
Khan T, Khan MA, Ullah N, Nadhman A (2020b) Therapeutic potential of medicinal plants against COVID-19: the role of antiviral medicinal metabolites. Biocatal Agric Biotechnol 31:101890

Kim DH, Gopal J, Sivanesan I (2017) Nanomaterials in plant tissue culture: the disclosed and undisclosed. RSC Adv 7(58):3649236505. https://doi.org/10.1039/C7RA07025J

Md Nesran ZN, Shafie NH, Md Tohid SF, Norhaizan ME, Ismail A (2020) Iron chelation properties of green tea epigallocatechin3-gallate (EGCG) in colorectal cancer cells: analysis on Tfr/Fth regulations and molecular docking. Evid Based Complement Altern Med 2020:7958041. https://doi.org/10.1155/2020/7958041

Mosavat N, Golkar P, Yousefifard M, Javed R (2019) Modulation of callus growth and secondary metabolites in different Thymus species and Zataria multiflora micropropagated under $\mathrm{ZnO}$ nanoparticles stress. Biotechnol Appl Biochem 66(3):316-322. https://doi. org/10.1002/bab.1727

Murashige T, Skoog F (1962) A revised medium for rapid growth and bio assays with tobacco tissue cultures. Physiol Plant 15(3):473497. https://doi.org/10.1111/j.1399-3054.1962.tb08052.x

Noman A, Aqeel M, Khalid N, Islam W, Sanaullah T, Anwar M, Khan S, Ye W, Lou Y (2019) Zinc finger protein transcription factors: Integrated line of action for plant antimicrobial activity. Microb Pathog 132:141-149. https://doi.org/10.1016/j.micpath.2019.04. 042

Rastogi A, Zivcak M, Sytar O, Kalaji HM, He X, Mbarki S, Brestic M (2017) Impact of metal and metal oxide nanoparticles on plant: a critical review. Front Chem 5:78

Rebaya A, Belghith SI, Baghdikian B, Leddet VM, Mabrouki F, Olivier E, Cherif J, Ayadi MT (2014) Total phenolic, total flavonoid, tannin content, and antioxidant capacity of Halimium halimifolium (Cistaceae). J Appl Pharm Sci 5(1):52-57

Srivastava V, Gusain D, Sharma YC (2013) Synthesis, characterization and application of zinc oxide nanoparticles $(\mathrm{n}-\mathrm{ZnO})$. Ceram Int 39(8):9803-9808

Xie X, Hu W, Fan X, Chen H, Tang M (2019) Interactions between phosphorus, zinc, and iron homeostasis in nonmycorrhizal and mycorrhizal plants. Front Plant Sci. https://doi.org/10.3389/fpls. 2019.01172

Yousaf R, Khan MA, Ullah N, Khan I, Hayat O, Shehzad MA, Khan I, Taj F, Ud Din N, Khan A (2019) Biosynthesis of anti-leishmanial natural products in callus cultures of Artemisia scoparia. Artif Cells Nanomed Biotechnol 47(1):1122-1131

Yusefi-Tanha E, Fallah S, Rostamnejadi A, Pokhrel LR (2020) Zinc oxide nanoparticles (ZnONPs) as a novel nanofertilizer: Influence on seed yield and antioxidant defense system in soil grown soybean (Glycine max cv. Kowsar). Sci Total Environ 738:140240. https://doi.org/10.1016/j.scitotenv.2020.140240

Zeb A (2015) A reversed phase HPLC-DAD method for the determination of phenolic compounds in plant leaves. Anal Methods 7(18):7753-7757. https://doi.org/10.1039/C5AY01402F

Zia M, Faisala S, Shams DF, Anjumd F, Saeed M, Shah ZU, Nadhman A (2021) Degradation of polyethylene plastic by non-embedded visible-light iron-doped zinc oxide nanophotocatalyst. Appl Sci Converg Technol 30(3):87-91

Publisher's Note Springer Nature remains neutral with regard to jurisdictional claims in published maps and institutional affiliations. 